\title{
One Example of a Model Humanitarian Mission
}

\author{
David R. Welling ${ }^{1} \cdot$ Norman M. Rich ${ }^{1} \cdot$ Eric Elster $^{1}$
}

Published online: 31 March 2015

(C) Société Internationale de Chirurgie 2015

\begin{abstract}
This paper describes a model humanitarian mission to Guyana; it illustrates the value of excellent ongoing care in collaboration with local physicians and surgeons, cooperation with local government and medical officials, and frequent periodic follow-up missions (always to the same hospital, working with the same staff). This effort has largely avoided the so-called "Seven Sins of Humanitarian Medicine".
\end{abstract}

\section{Introduction}

In July 2010, several of us who are associated with the Uniformed Services University of the Health Sciences published an article in World Journal of Surgery entitled "Seven Sins of Humanitarian Medicine" [1], which was meant to point out some of the areas where we might improve our efforts as we go forth to deliver proper health care to those in need throughout the world. This article stimulated some interesting discussion, and hopefully was useful to those who plan and carry out humanitarian missions. The so-called "seven sins" mentioned in this article included the following

Leaving a mess behind.

Failing to match technology to local needs and abilities. Failing of NGOs to cooperate and help each other, and to cooperate and accept help from military organizations. Failing to have a follow-up plan.

David R. Welling

david.welling@usuhs.edu

1 Norman M. Rich Department of Surgery, Uniformed Services University of the Health Sciences, 4301 Jones Bridge Road, Bethesda, MD 20814-4712, USA
Allowing politics, training, or other distracting goals to trump service, while representing the mission as "service".

Going where we are not wanted, or needed and/or being poor guests.

Doing the right thing for the wrong reason.

The tone of our article was purposefully somewhat negative. A better approach to this subject might be to emphasize the positive, as we discover missions which carefully are avoiding the so-called "Sins" we had described. This brief report is about one such mission, an ongoing effort to bring transplant surgery to Guyana.

A Description of the Mission to Guyana: in 2008, a chance meeting occurred between a transplant surgeon, Dr. Rahul Jindal (Professor of Surgery at the Uniformed Services University) and Mr. George Subraj, a philanthropist from New York City [2]. Mr. Subraj was originally from Guyana and was very interested in helping the citizens there who were suffering from renal failure. Hemodialysis was very limited in the country and was too expensive for the vast majority of its citizens (dialysis was costing $\$ 200$ per treatment, and the gross average income of someone in Guyana was only \$2900). As a result, patients with renal failure were simply allowed to die of their disease. Dr. Jindal began collaborating with Mr. Subraj, beginning with a trip to Guyana to learn of the problems and challenges there, and later establishing ties with government leaders 
and medical facilities, in order to begin to make a difference for these patients. Mr. Subraj has generously financed all aspects of these mission trips to his home country. A private hospital, the Balwant Singh Hospital in the capital city of Georgetown, was eventually chosen as the best facility for doing these transplants. A tissue typing and crossmatching effort was then launched, which was supported by the Immunology Department of Walter Reed National Military Medical Center (WRNMMC), Bethesda, Maryland, ensuring quality control over this important piece of the puzzle. Drexel University began providing similar support with pathology and with drug level testing. Peritoneal dialysis was introduced as a bridge to transplantation, and better vascular access procedures followed. Eventually, living related donor transplants were begun, the first in July 2008, using a kidney from a mother implanted into her 18-year-old son. The transplant teams, always led by Dr. Jindal, began quarterly trips to Guyana. Their last trip, as of October, 2014, occurred in August, 2014. It was the 20th mission, wherein the 25th and 26th kidney transplants were performed. As well, for the first time, Dr. Steve Waller, an ophthalmologist and humanitarian, was able to perform 6 corneal transplants, and has plans to further expand this effort as well. The next mission trip to Guyana will occur later this year (2014).

How well does the Guyana Mission fare, when comparing it to "The Seven Sins of Humanitarian Medicine"? one of us (DRW) was invited as an observer on a mission in July 2013, and came back with some impressions about how these activities were conducted, and whether they were effective in accomplishing their stated goals. The following are his observations

\section{Leaving a mess behind}

Over the years, more and more local physicians have been trained and are helping with all aspects of these transplants, including delivering anesthesia, performing radiologic procedures, and actually doing parts of the operations. The local physicians find candidates for surgery and for organ donation, and set up appointments for the planned transplants. And they carefully manage the patients post-operatively and are fully capable of caring for any complications which might arise. They therefore have a real sense of ownership of these patients. Also, using e-mail and Skype calls, Dr. Jindal and his team stay in close touch with the local physicians and continually make suggestions about anti-rejection medications, etc. As far as could be detected, no mess was left behind in this particular effort.
Failing to match technology to local needs and abilities

The Balwant Singh Hospital is a modern, well-equipped facility, with ultrasound, CT scan, and MRI capability [3]. Recently, a heart-lung machine has been purchased, and cardiac surgery has begun there. It appears that the hospital is well matched to the requirements of a transplantation center. Interestingly, by beginning to do transplantation surgery at this hospital, the entire hospital enterprise has been improved; capabilities have been increased, and even morale among their doctors and nurses seems to be elevated; they show a true sense of pride in becoming the only hospital in their country to be able to do transplantation surgery.

Failing of NGOs to cooperate and help each other, and to cooperate and accept help from military organizations

Since this particular mission is funded entirely by $\mathrm{Mr}$. George Subraj, there is no competition among NGOs, and no NGO is involved in this particular project.

\section{Failing to have a follow-up plan}

One of the most egregious mistakes of humanitarian medicine is the vile practice of going into a poor country, spending a few days, identifying patients with chronic diseases, and leaving a few weeks' supply of medicine for these patients, without any follow-up plan. Dr. Jindal's work in Guyana is truly a superb example of good followup, with frequent return visits, while assuring that local physicians are trained and capable of caring for patients between visits.

\section{Allowing politics, training, or other distracting goals to trump service, while representing the mission as "service"}

This simply does not describe what was observed there. The team is totally focused on the patients, their diseases, and their operations. The fact that the same group has returned to Guyana 20 times to do this important work speaks to the dedication of the members of this mission. The team is small, and the amount of work produced with each visit is prodigious. It exemplifies a service mission, pure and simple. 
Going where we are not wanted, or needed and/ or being poor guests

Before ever beginning to do transplant surgery, Dr. Jindal and Mr. Subraj visited local government officials and received assurances of help and support by them. This bond of friendship has continued up until today. Everyone in Guyana seems to be proud of this effort and is supportive. There have never been examples of being poor guests among the team members. Everyone agrees that this mission is both wanted and needed.

\section{Doing the right thing for the wrong reason}

The motives displayed by the team members seemed to be admirable ones. Nobody on the team was becoming rich, or famous, or gaining some sort of advantage by participating. If we go off on a humanitarian mission because it represents an interesting vacation, or an academic promotion, or for some other selfish reason, we have failed to grasp the true meaning of humanitarianism. We should be participating because we wish to stop pain, cure disease, and change a life for the better. Again, as a personal observer, one can attest that the members of this mission team were there for the right reasons.

Besides the efforts at transplantation, a parallel program in Guyana (and India) called the SEVAK is being run to screen poor villagers for premorbid conditions which might lead to eventual renal disease, like diabetes, hypertension, etc. This program, under the direction of a distinguished nephrologist Dr. T.G. Patel aims to preemptively attack and fix the root causes of renal failure [4].

\section{Summary and conclusion}

It is heartening to note that there are many such efforts ongoing throughout the world. Teams with proper motivation, with proper arrangements, with reasonable plans are making lives better. They are avoiding the pitfalls and traps of humanitarian medicine, the so-called "Sins". This one particular mission is a great example to all of us of how to conceive, organize, and run a model humanitarian effort.

Funding Funding for the Guyana missions is provided by $\mathrm{Mr}$. George Subraj, as explained in the manuscript.

\section{References}

1. Welling D, Ryan J, Burris D et al (2010) Seven sins of humanitarian medicine. World J Surg 35:466-470. doi:10.1007/ s00268-009-0373-Z

2. Babakhani A, Guy S, Falta E et al (2013) Surgeons bring RRT to patients in Guyana. Bull Am Coll Surg 98:17-27

3. Dr. Balwant Singh's Hospital (2014). http://drbalwantsinghshospi tal.com. Accessed 20 Oct 2014

4. SEVAK Project (2015). http://www.rediff.com/news/report/sevakproject-is-a-health-care-plan-for-the-villagers-and-by-the-villagers/ 20140108.htm. Accessed 18 Mar 2015 